\title{
How Mobile Home Residents Understand and Respond to Tornado Warnings
}

\author{
BROOKE FISHER LIU \\ Department of Communication, University of Maryland, College Park, College Park, Maryland \\ Michael EgNOTO ${ }^{\mathrm{a}}$ \\ National Consortium for the Study of Terrorism and Responses to Terrorism, University of Maryland, \\ College Park, College Park, Maryland \\ JUNGKYU RHYS LIM \\ Department of Communication, University of Maryland, College Park, College Park, Maryland
}

(Manuscript received 26 July 2017, in final form 19 February 2019)

\begin{abstract}
Mobile home residents experience higher fatality rates from tornadoes than "fixed home" residents. Yet, research on how mobile home residents understand and respond to tornado warnings is lacking. Such research can help meteorologists and their partners better communicate tornado risk. We conducted four surveys with residents of the southeastern United States. This region has the highest concentration of tornado fatalities and killer tornadoes, in part because of the high density of mobile homes. Findings reveal that today's tornado warning system inadequately prepares mobile home residents to respond safely to tornadoes. The study offers recommendations for how to improve tornado communication for mobile and fixed home residents.
\end{abstract}

\section{Introduction}

Tornadoes are one of nature's most violent storms (NOAA 2010). When the National Weather Service (NWS) issues a tornado warning, they recommend that people go to a basement, safe room, or interior room away from windows. If people are outside, the NWS recommends that they should seek shelter immediately inside a sturdy building. If people are in a vehicle, the NWS recommends that they should drive to the closest shelter if time allows (NWS 2018b). For mobile home residents, ${ }^{1}$ sheltering inside their home can be life threatening because their homes often are

\footnotetext{
${ }^{1}$ Mobile home residents live in housing that can be towed or placed without a dedicated foundation. Fixed home residents live in structures with foundations such as traditional houses or apartments.
}

\footnotetext{
${ }^{\text {a }}$ Current affiliation: The Walter Reed Army Institute of Research, Silver Spring, Maryland.
}

Corresponding author: Brooke Fisher Liu, bfliu@umd.edu not safe. Instead, the NWS recommends that mobile home residents abandon their homes immediately if they have access to a sturdy shelter (NWS 2018a). Unfortunately, mobile home residents may not have access to sturdy structures like a neighbor's home, a school, or a community shelter. Another challenge for mobile home residents is a lack of adequate advance tornado warning so they can shelter safely outside their homes. On average, there are only 13 minutes between a tornado warning and a tornado touchdown (NOAA 2011). Given these challenges and others, mobile home residents experience more casualties and severe injuries from tornadoes than "fixed home" residents (Donner 2007; Glass et al. 1980; Niederkrotenthaler et al. 2013; Schmidlin and King 1995).

One avenue for better preparing mobile home residents for tornadoes is effective risk communication, including tornado warnings. As Brooks and Doswell (2002) argued, "Efforts to improve safety practices and communication of forecast and warning information for this group [mobile home residents] will be especially important in the future, if the long-term decrease in tornado fatalities in the United States is going to continue" (p. 360). In this study, we examine 
mobile home residents' tornado preparedness, risk perception, information channel and source preferences, and tornado knowledge. We explore these factors through surveys with fixed and mobile home residents in the southeastern United States. This region has the highest concentration of tornado fatalities and killer tornadoes in the United States, in part because of high mobile home density (Ashley 2007; Brooks and Doswell 2002; NOAA 2015). Findings reveal that today's tornado warning system inadequately prepares mobile home residents to respond safely to tornadoes. The study offers recommendations for how to improve tornado communication for these residents.

\section{Literature review}

In 2000, the American Meteorological Society Council adopted a policy statement on tornado preparedness and safety, which called for continued outreach and research to reduce tornado-related fatalities and injuries (American Meteorological Society Council 2000). Here we synthesize the limited research on mobile home residents and tornadoes to address the policy statement. We also offer the study's research questions.

\section{a. How mobile home residents prepare for tornadoes}

Permanent home residents are more likely to have participated in tornado drills, have access to tornadoresistant shelters, and have an emergency response plan for seeking shelter, compared to mobile home residents (Chaney and Weaver 2010; Chaney et al. 2013). Few studies have examined why mobile home residents are less likely to prepare for and respond to tornadoes. One study found that some mobile home residents state it is "God's will" whether they survive, thus negating the need to prepare (Schmidlin et al. 2009). Some researchers have hypothesized that experience with prior false alarms explains why most mobile home residents inadequately prepare for and respond to tornado warnings (Schmidlin et al. 2009), although empirical research has not confirmed this hypothesis. In a similar vein, other research finds that prior tornado experience is not associated with higher levels of tornado preparedness among mobile home residents (Chaney et al. 2013). Given the limited prior research on mobile home residents' tornado preparedness, we ask $(\mathrm{RQ}=$ research question):

RQ1: To what extent do fixed and mobile home residents in the southeastern United States prepare for tornadoes?

\section{b. How mobile home residents receive and respond to tornado warnings}

Minimal research investigates how mobile home residents receive and respond to tornado warnings. One study found that mobile home residents could receive poor reception on their NOAA weather radios due to signal attenuation caused by the metal used to construct their homes (Troutman et al. 2001). Other researchers have called for investigations on how mobile home residents "go about organizing themselves for protective action during the often brief period prior to the onset of a tornado" (Donner 2007, p. 682). Researchers also have called for investigations on how to communicate tornado forecasts and warnings to mobile home residents (Brooks and Doswell 2002). For the general population, research finds that tornado warnings disseminated via a variety of sources [e.g., television (TV), outdoor warning sirens, and word-ofmouth communication] motivate action, if people have adequate knowledge to understand warnings and have access to shelter (Brown et al. 2002; Chiu et al. 2013; Comstock and Mallonee 2005; Liu et al. 1996). Most people receive tornado warnings from more than one source (Hammer and Schmidlin 2002).

Research finds that there is no single most effective information source for all warning recipients and that people generally need to receive similar information from multiple sources before taking action (Anthony et al. 2013; Liu et al. 2015). Once learning about a disaster, most people confirm the disaster through seeking information from a variety of sources and sharing information with friends and family (Liu et al. 2016; Mileti and Sorensen 1990). Information seeking occurs actively and passively. Active problem solvers initiate information searches whereas less active problem solvers are content to passively receive information when it comes their way (Kim and Krishna 2014; Kim 2016). Through active and passive communicative behaviors, people make meaning of a warning and decide how to respond (Bean et al. 2016; Kim 2016; Mileti and Sorensen 1990).

People's weather risk perceptions play an important role in how people respond to warnings (Hoekstra et al. 2011; Senkbeil et al. 2014). Propensity for daily risk taking also may affect how people respond to tornado warnings (Nicholson et al. 2005; Zinkhan and Karande 1991). However, we do not know to what extent these general findings about how people respond to warnings apply to mobile home residents' tornado responses. Therefore, we ask:

RQ2: Through which primary channels and sources do fixed and mobile home residents in the southeastern 
United States obtain information about tornado watches and warnings?

RQ3: How do fixed and mobile home residents in the southeastern United States evaluate their risk of tornadoes personally affecting them?

\section{c. Tornado knowledge}

We also assess whether tornado knowledge affects residents' capacity to respond to warnings. Prior research found that tornado hazard and warning knowledge impact how people respond to tornadoes (Liu et al. 1996; Schmidlin et al. 2009; Whitmer et al. 2017). However, individuals sometimes have false knowledge, often called tornado myths or tornado folk science (Klockow et al. 2014; LaNore 2014). For example, some people believe that "a green sky means that a tornado is coming", (LaNore 2014, p. 9), "hills stop tornadoes from pushing forward" (Klockow et al. 2014, p. 803), and "mobile homes are tornado magnets" (LaNore 2014, p. 43). A critical piece of knowledge is how to shelter safely during tornadoes (Hoekstra et al. 2011; Schmidlin et al. 2009). When the NWS issues a tornado warning, the primary recommended behavior for fixed home residents is to shelter in place. The primary recommended behavior for mobile home residents is to seek a safe shelter outside their homes (NWS 2018a). However, many mobile home residents seek shelter inside their homes during tornadoes rather than in safe locations outside their homes (Chaney and Weaver 2010; Chaney et al. 2013).

Mobile home residents may not leave their homes because they do not know where to evacuate to, when to leave, and which route to take to evacuate (Ash 2017). Furthermore, they might not seek shelter outside their homes because they think their mobile homes can withstand tornadoes and/or they believe that nearby fixed homes are not safer during tornadoes (Ash 2017). Other important tornado knowledge includes how tornadoes form, where safe places in structures are during tornadoes, if tornadoes can cross water or mountains (common misconceptions about tornadoes), tornado probabilities, and when tornadoes occur (Edwards 2017; NOAA 2010, 2011). We do not know to what extent residents possess accurate tornado knowledge. Therefore, we ask:

RQ4: What level of tornado knowledge do fixed and mobile home residents have in the southeastern United States?

\section{Method}

\section{a. Data collection and cleaning}

Four surveys with 4171 responses were collected between 8 July 2016 and 11 August 2016. A large survey company (Qualtrics) conducted the online surveys using a regionally representative sample of the southeastern United States based on a quota of age, income, gender, and racial/ethnic identity. The states of interest were Alabama, Arkansas, Florida, Georgia, Kentucky, Louisiana, Mississippi, North Carolina, South Carolina, Tennessee, Virginia, and West Virginia.

The surveys took approximately $30 \mathrm{~min}$ on average to complete (surveys 1 and 2: mean $M=42.1$, standard deviation $\mathrm{SD}=157.99$, and median Mdn = 26.37; surveys 3 and 4: $M=33.51, \mathrm{SD}=205.96$, and $\mathrm{Mdn}=19.78$ ). Responses under $30 \%$ of the median time were eliminated from analysis, as were responses more than 3 SDs above the median. After this data cleaning procedure, 2076 cases from surveys 1 and 2 remained for analysis, with a mean completion time of $35.87 \mathrm{~min}(\mathrm{SD}=37.96$; Mdn $=27.05$ ) and 1973 cases from surveys 3 and 4 with a mean completion time of $26.01 \mathrm{~min}(\mathrm{SD}=30.11$; $\mathrm{Mdn}=$ 19.93). Cases on the tail of the distribution were manually inspected, and no additional data concerns were uncovered.

The final dataset provided 3054 general residents (survey $1 N=1577$; survey $3 N=1477$ ) and 995 mobile home residents (survey $2 N=499$; survey $4 N=496$ ) of the southeastern United States that were appropriate for further analysis. The cases removed from the data cleaning procedure did not significantly impact any racial, gender, or age-based statistics, suggesting that the cases were fairly normally distributed. No other significant differences were uncovered between the samples in terms of race, age, location, or any reported demographics (Table 1).

\section{b. Measures}

The study's measures are summarized below. We also measured demographics.

\section{1) Channels And sources}

RQ2 asks about primary channels and sources. We tested 17 sources (e.g., friends, neighbors, and meteorologists) and nine communication channels (e.g., social media, phone, and sirens). The research asked the following question, "From what source(s) did you receive an alert?" with an option of each source and channel. Participants marked "yes" or "no," where "yes" meant they had learned about their last tornado event from that source or channel and "no" meant they did not receive information about their last tornado event from that source or channel. No Cronbach's $\alpha$ is reported because of the dichotomous nature of the measure.

\section{2) INFORMATION MILLING}

RQ2 asks about primary channels and sources. Information milling examines passive communicative 
TABLE 1. Survey demographics. Some respondents identified multiple races and genders, and therefore race and gender variables were not aggregated.

\begin{tabular}{|c|c|c|c|c|c|}
\hline Variable & $N$ & Time & Race & Gender & Age \\
\hline $\begin{array}{l}\text { Survey } 1 \\
\quad \text { (fixed home residents) }\end{array}$ & 1577 & 35.87 (SD 37.96) & $\begin{array}{l}\text { Caucasian } 70.7 \% \\
\text { African American/Black } 22.0 \% \\
\text { Asian } 1.8 \% \\
\text { Hispanic } 6.7 \% \\
\text { Native American } 0.0 \% \\
\text { Other } 0.0 \%\end{array}$ & $\begin{array}{l}\text { Male } 49.2 \% \\
\text { Female } 50.2 \% \\
\text { Other } 0.6 \%\end{array}$ & 44.5 (SD 17.30) \\
\hline $\begin{array}{l}\text { Survey } 2 \\
\quad \text { (mobile home residents) }\end{array}$ & 499 & $39.68(\mathrm{SD} 41.13)$ & $\begin{array}{l}\text { Caucasian } 82.8 \% \\
\text { African American/Black } 12.0 \% \\
\text { Asian } 1.0 \% \\
\text { Hispanic } 2.8 \% \\
\text { Native American } 1.2 \% \\
\text { Other } 2.0 \%\end{array}$ & $\begin{array}{l}\text { Male } 29.0 \% \\
\text { Female } 70.4 \% \\
\text { Other } 0.6 \%\end{array}$ & 45.7 (SD 16.96) \\
\hline $\begin{array}{l}\text { Survey } 3 \\
\quad \text { (fixed home residents) }\end{array}$ & 1477 & $25.89(\mathrm{SD} 29.85)$ & $\begin{array}{l}\text { Caucasian } 68.1 \% \\
\text { African American/Black } 23.4 \% \\
\text { Asian } 2.1 \% \\
\text { Hispanic } 7.6 \% \\
\text { Native American } 0.0 \% \\
\text { Other } 0.0 \%\end{array}$ & $\begin{array}{l}\text { Male } 49.6 \% \\
\text { Female } 50.0 \% \\
\text { Other } 0.3 \%\end{array}$ & 44.5 (SD 17.30) \\
\hline $\begin{array}{l}\text { Survey } 4 \\
\quad \text { (mobile home residents) }\end{array}$ & 496 & 26.37 (SD 31.02) & $\begin{array}{l}\text { Caucasian } 79.2 \% \\
\text { African American/Black } 14.4 \% \\
\text { Asian } 1.8 \% \\
\text { Hispanic } 3.6 \% \\
\text { Native American } 2.8 \% \\
\text { Other } 1.8 \%\end{array}$ & $\begin{array}{l}\text { Male } 33.7 \% \\
\text { Female } 65.3 \% \\
\text { Other } 1.0 \%\end{array}$ & 45 (SD 16.96) \\
\hline Total & 4049 & - & - & - & - \\
\hline
\end{tabular}

behaviors (information receiving) and active communicative behaviors (information seeking and sharing). In other words, we examined from what channels people receive a tornado warning and what channels people use to seek and share additional information (see Table 6, below). Thirteen channels from which people receive tornado warnings and 16 information seeking and sharing behaviors were assessed by asking participants to recall their last tornado experience and to state whether they participated in active or passive communicative behaviors on a 1-7 scale with an option of "not applicable." No Cronbach's $\alpha$ could be computed because questions were single-item measures designed to report on specific behaviors rather than contribute to one overarching concept.

\section{3) Perceived false alarm Rate}

RQ1 asks about preparedness that may be related to perceived false alarm rates. Prior research provided mixed findings on whether perceived and/or actual false alarm rates affect people's protective behaviors in response to tornado warnings (e.g., Simmons and Sutter 2009; Trainor et al. 2015). To assess the perceived false alarms rate, we used a modified version of Trainor et al.'s (2015) scale and asked participants to answer the following question: "How frequent do you perceive false alarms to be for tornadoes in your area?," with responses on a $0-100$ scale. We also asked participants to rate on the same scale whether they believe "false alarms occur frequently in my area," where 0 was "completely disagree" and 100 was "completely agree." No Cronbach's $\alpha$ is reported because of the nature of the measure.

\section{4) Perceived tornado PReParedness}

RQ1 asks about preparedness. People's perceptions of their own disaster preparedness affect whether they take protective actions during an event, based in part on how well they feel they were prepared for prior events (Dillon et al. 2014). Fixed and mobile home residents' current tornado preparedness, including access to shelter, was measured with five items ranging from strongly disagree to strongly agree on a 7-point Likert-type scale. The measure asked whether participants agreed with five statements like "I have access to adequate shelter," "I have adequate supplies stored in my home in case of a tornado," and "My family knows what to do in case of a tornado." The preparedness measure had a Cronbach's $\alpha$ of 0.81 . A principal component analysis with varimax rotation found only one axis in the solution set, indicating that all variables loaded on a single factor. 


\section{5) Religiosity}

RQ1 asks about preparedness, which may be related to religiosity (Schmidlin et al. 2009). Religiosity was assessed by measuring participants' general intensities on five core dimensions of religiosity with five Likert-type questions on a 1 to 5 scale (Huber and Huber 2012). The five dimensions are public practice, private practice, religious experience, ideology, and intellectual dimensions. Questions include: "How often you do you think about religious issues" and "How often do you take part in religious services?" Cronbach's $\alpha$ was 0.89 , and principal component analysis indicated a one-factor solution.

\section{6) Perceived Risk: Tornado}

RQ3 asks about risk evaluation. Individuals' perceived risk has long been studied, and personalizing risk is an important precondition for protective action (Mason et al. 2018; van der Pligt et al. 1993; Weber 2006). Following previous research (Dillon et al. 2014), we asked participants about their holistic judgement of tornado risk with the following questions on a $0-10$ scale, where 0 is no risk and 10 is extremely risky: 1 ) "Based on your prior experience, how great a risk do you think tornadoes now pose to you?"; 2) "How great of a risk do tornadoes pose to the United States as a whole?"; and 3) "How great of a risk do tornadoes pose to the southeastern United States?" Cronbach's $\alpha$ was 0.76 , and principal component analysis indicated a one-factor solution. The three questions were aggregated into a perceived risk scale. We asked different questions about tornado risk as opposed to risk propensity (Nicholson et al. 2005) because people report general risk, specific risk, and personal or family risk drastically differently and people describe themselves as subjected to less risk than others (Duck and Mullin 1995; Gunther and Mundy 1993).

\section{7) PeRCEIVED RISK: RISK PROPENSITY}

RQ3 asks about risk evaluation. Risk propensity is "the tendency of a decision maker either to take or to avoid risks" (Sitkin and Pablo 1992, p. 12). This variable measured risk across different domains constructed from prior research (Nicholson et al. 2005). Risk propensity is a composite scale, which assesses an individual's comfort with dangerous behavior like smoking and safety risks at work. Specifically, a 12-item measure ranging from 1 ("never") to 5 ("always") assessed people's self-reported behaviors in health risks (e.g., smoking), recreational risks (e.g., dangerous sports), career risks, financial risks, safety risks (e.g., aggressive driving), and social risks (e.g., challenging authority) in current everyday life and in the past. Cronbach's $\alpha$ was 0.949 .

\section{8) SELF-EFFICACY}

RQ1 asks about preparedness that may be related to self-efficacy. Self-efficacy to take shelter during a tornado was assessed using a previously established measure, but applied to a tornado context (So et al. 2015; Witte et al. 1996). Four questions focused on individuals' current perceived ability to impact the outcome of a tornado and asked questions like "How capable are you at effectively taking shelter when responding to a tornado?" and "How easy would it be for you to take shelter in a tornado?" measured on a 1-10 Likert-type scale ranging from strongly agree to strongly disagree. Cronbach's $\alpha$ was 0.947 , and principal component analysis indicated a one-factor solution.

\section{9) ToRnAdo KNOWLEDGE AND UnDERSTANDING} GUIDANCE

RQ4 asks about tornado knowledge. Fifteen questions pulled from NOAA educational materials (Edwards 2017; NOAA 2010, 2011) assessed whether people had the foundational knowledge to understand NOAA protective action recommendations, like sheltering in place. Questions were multiple choice and true/false. Sample questions include, "True or false, tornadoes never strike the same place twice," "True or false, tornadoes cannot cross water," and "If you are inside a house during a tornado, where should you go?" All answers were collected with the participants' responses. Then, the participants' responses were recoded into a new binary variable with 0 (when participants chose the wrong response) and 1 (when participants chose the right response). Subsequently, the team created a knowledge score by adding the number of correct answers, divided by the total number of questions, and multiplied by 100 .

\section{0) TRUST IN GOVERNMENT WARNINGS}

RQ1 asks about preparedness of southeastern U.S. residents for tornadoes, including residents' trust that the government will adequately warn them about tornadoes. We asked the following question: "I trust that the government will give me as much warning as they can about impending tornadoes" measured on a 1-7 Likert-type scale ranging from "strongly disagree" to "strongly agree." No Cronbach's $\alpha$ was measured for this single-item measure.

\section{Results}

\section{a. Understanding preparedness (RQ1)}

We examined how prepared fixed and mobile home residents are in the southeastern U.S. in advance of 
TABLE 2. Perceived preparedness, access to shelter, and self-efficacy to take shelter by mobile home and fixed home residents (one asterisk for $p<0.05$, two asterisks for $p<0.01$, and three asterisks for $p<0.001$ ).

\begin{tabular}{|c|c|c|c|c|c|c|c|c|c|c|}
\hline & \multicolumn{3}{|c|}{ Mobile home residents } & \multicolumn{3}{|c|}{$\begin{array}{l}\text { Fixed home } \\
\text { residents }\end{array}$} & \multicolumn{2}{|c|}{$\begin{array}{l}95 \% \text { confidence } \\
\text { interval }(\mathrm{CI}) \text { for } \\
\text { mean diff }\end{array}$} & \multirow[b]{2}{*}{$t$} & \multirow[b]{2}{*}{ df } \\
\hline & $M$ & SD & $n$ & $M$ & SD & $n$ & Lower & Upper & & \\
\hline Perceived preparedness & 4.352 & 1.22 & 985 & 4.85 & 1.21 & 3013 & 0.417 & 0.5931 & $11.82^{* * * *}$ & 3996 \\
\hline Perceived access to shelter & 3.32 & 1.9 & 997 & 4.7 & 1.74 & 3045 & 1.243 & 1.509 & $20.244^{* * *}$ & 1582.022 \\
\hline Confidence knowing tornado signs & 4.68 & 1.55 & 994 & 4.86 & 1.50 & 3041 & 0.064 & 0.285 & $3.092^{* *}$ & 1636.458 \\
\hline Trust in government warnings & 4.67 & 1.63 & 994 & 5.03 & 1.48 & 3042 & 6.13 & 1560.115 & $0.244^{* * * *}$ & 0.473 \\
\hline Adequate supplies stored & 4.19 & 1.78 & 991 & 4.62 & 1.67 & 3036 & 0.306 & 0.558 & $6.716^{* * * *}$ & 1598.49 \\
\hline Family knowledge about a tornado & 4.89 & 1.65 & 994 & 5.06 & 1.52 & 3032 & 0.051 & 0.284 & $2.812^{* *}$ & 1580.428 \\
\hline Self-efficacy to take shelter & 7.0308 & 2.44 & 479 & 7.66 & 2.07 & 1429 & 0.386 & 0.8742 & $5.073^{* * *}$ & 73.031 \\
\hline
\end{tabular}

tornadoes. In aggregate, fixed home residents reported $(M=4.85 ; \mathrm{SD}=1.21)$ significantly higher levels of preparedness than mobile home residents $(M=4.35$; $\mathrm{SD}=1.22)$, as indicated by an independent samples $t$ test $[t(3996)=11.282 ; p<0.001]$. Moreover, fixed home residents reported $(M=7.66 ; \mathrm{SD}=2.07)$ significantly higher levels of self-efficacy to take shelter than mobile home residents $(M=7.03$; SD $=2.44)$, as indicated by an independent sample $t$ test $[t(723.031)=$ 5.073; $p<0.001]$. Specifically, independent sample $t$ test results showed that mobile home residents perceived the following factors to be lower compared to fixed home residents: access to adequate shelter, physical supplies stored, trust that the government will give as much warning as they can about impending tornadoes, confidence in personal ability to handle a tornado, and family knowledge about tornadoes (Table 2).

Possibly, mobile home residents could perceive that they are less prepared because they believe that it is God's will whether they survive a tornado, thus negating the need for them to prepare (Schmidlin et al. 2009). We examined whether there are differences in religiosity between mobile and fixed home residents. Mobile home residents $(M=3.54$; $\mathrm{SD}=1.06)$ were slightly more religious than fixed home residents $(M=3.43$; SD $=1.08)[t(1964)=$ $-2.039 ; p<0.05]$, yet the difference was small (Table 3).

Mobile home residents could perceive that they are less prepared because they perceive higher false alarms rates (Schmidlin et al. 2009). However, an independent sample $t$ test showed that mobile home residents $(M=35.58 ; \mathrm{SD}=26.94)$ perceived a lower false alarm rate than fixed home residents $(M=38.60 ; \mathrm{SD}=28.35)$ $(t=2.996$; degrees of freedom $\mathrm{df}=1738.415 ; p<0.01)$. Of note, the perceived false alarm rate had a high SD (Table 4).

\section{b. Primary channels and sources (RQ2)}

Fixed and mobile home residents predominately relied on the same sources and channels for tornado information, with the notable exception that mobile home residents were less accessible on social media and more dependent on their local TV meteorologist (Table 5).

Results further indicated significant differences in information milling behavior (i.e., from what channels residents receive information about tornado warnings and where they go to seek and share additional tornado information). Mobile home residents almost universally reported less information milling

TABLE 3. Religiosity between mobile home and fixed home residents (one asterisk for $p<0.05$, two asterisks for $p<0.01$, and three asterisks for $p<0.001)$.

\begin{tabular}{|c|c|c|c|c|c|c|c|c|c|c|}
\hline & \multicolumn{3}{|c|}{ Mobile home residents } & \multicolumn{3}{|c|}{ Fixed home residents } & \multicolumn{2}{|c|}{$95 \%$ CI for mean diff } & \multirow[b]{2}{*}{$t$} & \multirow[b]{2}{*}{ df } \\
\hline & $M$ & SD & $n$ & $M$ & SD & $n$ & Lower & Upper & & \\
\hline Religiosity & 3.54 & 1.06 & 498 & 3.43 & 1.08 & 1468 & -0.223 & -0.004 & $-2.039^{*}$ & 1964 \\
\hline Intellect & 3.37 & 1.28 & 500 & 3.28 & 1.24 & 1485 & -0.215 & 0.04 & -1.353 & 1983 \\
\hline Public practice & 2.89 & 1.36 & 499 & 2.86 & 1.34 & 1482 & -0.165 & 0.109 & -0.403 & 1979 \\
\hline Private practice & 3.68 & 1.28 & 499 & 3.53 & 1.32 & 1480 & -0.278 & -0.012 & $-2.134^{*}$ & 1977 \\
\hline Experience & 3.53 & 1.28 & 500 & 3.38 & 1.30 & 1484 & -0.276 & -0.013 & $-2.155^{*}$ & 1982 \\
\hline Ideology & 4.27 & 1.16 & 499 & 4.11 & 1.25 & 1482 & -0.292 & -0.042 & $-2.628^{* * *}$ & 1979 \\
\hline
\end{tabular}


TABLE 4. Perceived false alarm rate between mobile home and fixed home residents (one asterisk for $p<0.05$, two asterisks for $p<0.01$, and three asterisks for $p<0.001)$.

\begin{tabular}{|c|c|c|c|c|c|c|c|c|c|c|}
\hline & \multicolumn{3}{|c|}{ Mobile home residents } & \multicolumn{3}{|c|}{ Fixed home residents } & \multicolumn{2}{|c|}{$95 \% \mathrm{CI}$ for mean diff } & \multirow[b]{2}{*}{$t$} & \multirow[b]{2}{*}{ df } \\
\hline & $M$ & SD & $n$ & $M$ & SD & $n$ & Lower & Upper & & \\
\hline Perceived false alarm rate & 35.58 & 26.94 & 977 & 38.60 & 28.35 & 2980 & 1.04 & 4.98 & $2.996^{* * *}$ & 1738.415 \\
\hline
\end{tabular}

behavior, although mobile home and fixed home residents did not use significantly different primary channels. Television, face-to-face interactions, and phone calls/texts were the primary channels for information exchange during tornadoes. See Table 6 for more information.

\section{c. Evaluations of tornado risk (RQ3)}

To examine risk perception, we compared risk propensity between mobile and fixed home residents. With the exception of personal health risks (smoking and drinking), mobile home residents had lower risk propensity and were significantly less likely to take risks $[t(1968.926)=6.837 ; p<0.001]$ than fixed home residents across dimensions (Table 7 ).

To further examine risk perception for tornadoes, independent sample $t$ tests determined if there were meaningful differences between the two groups of residents in their perceived risk of tornadoes. Results indicated no significant differences between mobile home residents $(M=7.407 ; \mathrm{SD}=1.939)$ and fixed home residents $(M=7.444 ; \mathrm{SD}=1.646)$ $[t(392.374)=0.269 ; p=0.788]$.

\section{d. Tornado knowledge (RQ4)}

To address RQ4, participants responded to a series of questions derived from NOAA educational materials (Edwards 2017; NOAA 2011, 2017). Independent sample's $t$ test results $[t(1833.373)=-4.520 ; p<0.001]$ identified that mobile home residents had slightly higher tornado knowledge rates $(M=71.22 ; \mathrm{SD}=16.11)$ than fixed home residents $(M=68.38$; SD $=18.43)$ (Table 8). Still, there is a room for improvement for mobile and fixed home residents' knowledge in responses to tornadoes. In particular, more than a half of mobile and fixed home residents had the wrong information that "the northeast corner of a basement is the safest location during passage of a tornado" and "if you're driving, you should take shelter under a bridge during a tornado."

Unfortunately, mobile and fixed home residents seem to be missing some critical knowledge about the proper protective action to take when in mobile homes during tornadoes. When specifically asked what protective action you should take in a mobile home when a tornado occurs, only $54 \%$ of mobile home participants correctly responded that they should abandon the mobile home and seek shelter in a sturdy, nearby structure. In other words, about half of the respondents did not have proper knowledge of the recommended protective action (Table 9). Specifically, about $42 \%$ of mobile home participants responded that they should seek shelter inside in a low interior room (like a bathroom), while $3 \%$ chose that they should retreat to a nearby vehicle. Fixed home residents also seemed to be missing knowledge about how mobile home residents should protect themselves during tornadoes, although their knowledge was slightly higher than the knowledge of mobile home respondents in our survey. Specifically, when participants residing in fixed homes were asked what to do in a mobile home during a tornado, about $63 \%$ of them answered correctly. However,

TABLE 5. Communication channels and sources for tornado watches and warnings (note that percentages do not add to $100 \%$ because individuals could select multiple responses).

\begin{tabular}{|c|c|c|}
\hline Category & $\begin{array}{l}\text { Fixed } \\
\text { homes }\end{array}$ & $\begin{array}{l}\text { Mobile } \\
\text { homes }\end{array}$ \\
\hline \multicolumn{3}{|l|}{ Channels } \\
\hline Traditional media & $38 \%$ & $39 \%$ \\
\hline Scrolling ticker & $31 \%$ & $31 \%$ \\
\hline Social media & $22 \%$ & $17 \%$ \\
\hline Text from emergency services (WEA) & $22 \%$ & $26 \%$ \\
\hline Text from loved ones & $16 \%$ & $17 \%$ \\
\hline Siren & $15 \%$ & $11 \%$ \\
\hline Face to face & $6 \%$ & $5 \%$ \\
\hline \multicolumn{3}{|l|}{ Sources } \\
\hline Local TV meteorologist & $40 \%$ & $46 \%$ \\
\hline National TV meteorologist & $14 \%$ & $14 \%$ \\
\hline Media (other than meteorologist) & $14 \%$ & $14 \%$ \\
\hline Friends & $13 \%$ & $10 \%$ \\
\hline NOAA & $8 \%$ & $7 \%$ \\
\hline Coworkers & $8 \%$ & $4 \%$ \\
\hline Other government agency & $7 \%$ & $4 \%$ \\
\hline Neighbors & $6 \%$ & $5 \%$ \\
\hline Parents & $6 \%$ & $5 \%$ \\
\hline Fire department & $6 \%$ & $3 \%$ \\
\hline Spouse & $5 \%$ & $5 \%$ \\
\hline Police & $4 \%$ & $2 \%$ \\
\hline Siblings & $2 \%$ & $3 \%$ \\
\hline
\end{tabular}


TABLE 6. Information milling preferences (one asterisk for $p<0.05$, two asterisks for $p<0.01$, and three asterisks for $p<0.001$ ).

\begin{tabular}{|c|c|c|c|c|c|c|}
\hline Variable & Fixed & Mobile & Total & df & $F$ & $p$ \\
\hline \multicolumn{7}{|c|}{ Information receiving } \\
\hline Local newspaper ${ }^{* * * *}$ & $3.73(2.39)$ & $3.04(2.29)$ & $3.55(2.38)$ & 1,1980 & 31.438 & 0.000 \\
\hline National newspaper ${ }^{* * * *}$ & $3.57(2.35)$ & $2.95(2.27)$ & $3.42(2.34)$ & 1,1971 & 26.256 & 0.000 \\
\hline TV & $6.13(1.23)$ & $6.15(1.30)$ & $6.13(1.25)$ & 1,1978 & 0.086 & 0.769 \\
\hline Local govt. websites ${ }^{* * * *}$ & $4.70(2.03)$ & $4.19(2.13)$ & $4.57(2.07)$ & 1,1974 & 22.283 & 0.000 \\
\hline Federal websites ${ }^{* * *}$ & $4.36(2.11)$ & $3.79(2.15)$ & $4.21(2.13)$ & 1,1981 & 27.058 & 0.000 \\
\hline Online videos ${ }^{* * * *}$ & $3.74(2.29)$ & $3.10(2.15)$ & $3.58(2.27)$ & 1,1982 & 29.878 & 0.000 \\
\hline Facebook $^{*}$ & $4.31(2.28)$ & $4.04(2.32)$ & $4.24(2.29)$ & 1,1982 & 4.912 & 0.027 \\
\hline Twitter ${ }^{* * * *}$ & $3.99(2.45)$ & $3.48(2.46)$ & $3.86(2.46)$ & 1,1960 & 15.923 & 0.000 \\
\hline $\mathrm{Blog} \mathrm{s}^{* * * *}$ & $3.63(2.40)$ & $3.11(2.32)$ & $3.50(2.39)$ & 1,1949 & 17.483 & 0.000 \\
\hline Face to face/telephone & $5.00(1.96)$ & $4.96(2.05)$ & $4.99(1.98)$ & 1,1975 & 0.155 & 0.693 \\
\hline E-mail friends/family ${ }^{* * *}$ & $3.86(2.26)$ & $3.26(2.26)$ & $3.71(2.27)$ & 1,1973 & 25.938 & 0.000 \\
\hline Text & $4.88(2.14)$ & $4.72(2.30)$ & $4.84(2.18)$ & 1,1973 & 1.949 & 0.163 \\
\hline Flickr, Pinterest, etc. ${ }^{* * * *}$ & $3.98(2.33)$ & $3.55(2.40)$ & $3.87(2.35)$ & 1,1983 & 12.223 & 0.000 \\
\hline \multicolumn{7}{|c|}{ Information seeking and sharing } \\
\hline Like a post on social media* & $3.77(2.36)$ & $3.50(2.35)$ & $3.70(2.36)$ & 1,1983 & 5.061 & 0.025 \\
\hline Retweet $^{*}$ & $3.92(2.43)$ & $3.64(2.54)$ & $3.85(2.46)$ & 1,1987 & 4.929 & 0.027 \\
\hline E-mail website ${ }^{* * * *}$ & $3.51(2.27)$ & $3.06(2.24)$ & $3.40(2.27)$ & 1,1983 & 15.148 & 0.000 \\
\hline Face to face & $5.16(1.94)$ & $5.12(2.06)$ & $5.15(1.97)$ & 1,1983 & 0.141 & 0.708 \\
\hline E-mail ${ }^{* * *}$ & $4.30(2.23)$ & $3.86(2.36)$ & $4.19(2.27)$ & 1,1984 & 13.974 & 0.000 \\
\hline Telephone & $5.33(1.87)$ & $5.38(2.03)$ & $5.34(1.91)$ & 1,1988 & 0.263 & 0.608 \\
\hline Text & $5.11(2.09)$ & $5.00(2.23)$ & $5.08(2.13)$ & 1,1977 & 0.984 & 0.321 \\
\hline Like posts ${ }^{* *}$ & $3.78(2.40)$ & $3.35(2.37)$ & $3.67(2.40)$ & 1,1976 & 12.031 & 0.001 \\
\hline Share posts ${ }^{*}$ & $4.06(2.41)$ & $3.74(2.47)$ & $3.98(2.43)$ & 1,1973 & 6.542 & 0.011 \\
\hline Comment on Facebook $^{* * *}$ & $3.73(2.36)$ & $3.20(2.33)$ & $3.60(2.36)$ & 1,1974 & 18.603 & 0.000 \\
\hline Post information on others' Facebook ${ }^{* *}$ & $3.98(2.37)$ & $3.60(2.45)$ & $3.89(2.39)$ & 1,1983 & 9.861 & 0.002 \\
\hline Write a blog ${ }^{* * * *}$ & $3.60(2.50)$ & $3.14(2.45)$ & $3.48(2.50)$ & 1,1973 & 12.448 & 0.000 \\
\hline Post on others' blog ${ }^{* * * *}$ & $3.66(2.46)$ & $3.17(2.41)$ & $3.54(2.45)$ & 1,1970 & 14.736 & 0.000 \\
\hline Comment on videos ${ }^{* *}$ & $3.63(2.43)$ & $3.20(2.39)$ & $3.52(2.43)$ & 1,1975 & 12.02 & 0.001 \\
\hline Upload relevant photographs ${ }^{* * *}$ & $3.68(2.42)$ & $3.21(2.38)$ & $3.57(2.42)$ & 1,1979 & 14.101 & 0.000 \\
\hline Follow relevant sources on Facebook & $4.19(2.37)$ & $4.02(2.48)$ & $4.15(2.39)$ & 1,1979 & 1.814 & 0.178 \\
\hline
\end{tabular}

$30 \%$ responded that they should seek shelter in the hallway, bathroom, or closet, and $6 \%$ responded that mobile home residents should retreat to a nearby vehicle $\left[\chi^{2}(2)=53.772 ; p<0.001\right]$.

\section{Discussion}

This research set out to understand how mobile home residents respond to tornadoes, given the dearth of research on this topic. Below we discuss the findings by research question.

\section{a. Tornado preparedness (RQ1)}

Mobile home residents displayed a pattern of lower preparedness, lower self-efficacy to take shelter, lower trust that the government will provide as much warning as they can about impending tornadoes, and lower access to shelter, compared to fixed home residents. These

TABLE 7. Risk propensity between mobile home and fixed home residents (one asterisk for $p<0.05$, two asterisks for $p<0.01$, and three asterisks for $p<0.001)$.

\begin{tabular}{|c|c|c|c|c|c|c|c|c|c|c|}
\hline & \multicolumn{3}{|c|}{ Mobile home residents } & \multicolumn{3}{|c|}{ Fixed home residents } & \multicolumn{2}{|c|}{$95 \%$ CI for mean diff } & \multirow[b]{2}{*}{$t$} & \multirow[b]{2}{*}{ df } \\
\hline & $M$ & SD & $n$ & $M$ & SD & $n$ & Lower & Upper & & \\
\hline Risk propensity & 1.87 & 0.87 & 957 & 2.11 & 1.05 & 2876 & 0.167 & 0.302 & $6.837^{* * * *}$ & 1968.92 \\
\hline Recreational & 1.63 & 1.02 & 985 & 1.98 & 1.23 & 2949 & 0.268 & 0.424 & $8.71^{* * * *}$ & 2013.89 \\
\hline Health & 2.58 & 1.41 & 979 & 2.54 & 1.32 & 2941 & -0.138 & 0.062 & -0.735 & 1585.82 \\
\hline Career & 1.78 & 1.03 & 982 & 1.99 & 1.18 & 2936 & 0.137 & 0.293 & $5.435^{\text {**** }}$ & 1912.89 \\
\hline Finance & 1.78 & 1.05 & 980 & 2.06 & 1.22 & 2937 & 0.197 & 0.356 & $6.844^{* * * *}$ & 1921.52 \\
\hline Safety & 1.84 & 1.10 & 981 & 2.09 & 1.24 & 2938 & 0.165 & 0.330 & $5.898^{* * * *}$ & 1863.58 \\
\hline Social & 1.65 & 1.04 & 979 & 1.99 & 1.24 & 2938 & 0.259 & 0.418 & $8.354^{* * * *}$ & 1973.52 \\
\hline
\end{tabular}


TABLE 8. Answers to questions about mobile home and fixed home residents' tornado knowledge. Given are the count and the percent (in parentheses).

\begin{tabular}{|c|c|c|c|c|c|}
\hline Questions & Answers & Fixed & Mobile & Total & \\
\hline \multirow{2}{*}{$\begin{array}{l}\text { Choose true or false: if a } \\
\text { tornado is coming toward } \\
\text { your house, you should } \\
\text { open the windows }\end{array}$} & Right (false) & $1938(65.9)$ & $645(66.2)$ & $2583(66.0)$ & \multirow[t]{2}{*}{$\chi^{2}(1)=0.35 ; p>0.05$} \\
\hline & Wrong (true) & $1003(34.1)$ & $329(33.8)$ & $1332(34.0)$ & \\
\hline \multirow{2}{*}{$\begin{array}{l}\text { Choose true or false: } \\
\text { tornadoes can cross water }\end{array}$} & Right (true) & $2458(84.2)$ & $834(84.5)$ & $3292(84.6)$ & \multirow{2}{*}{$\chi^{2}(1)=1.425 ; p>0.05$} \\
\hline & Wrong (false) & $461(15.8)$ & $138(14.2)$ & $599(15.4)$ & \\
\hline \multirow{2}{*}{$\begin{array}{l}\text { Choose true or false: the } \\
\text { northeast corner of a } \\
\text { basement is the safest } \\
\text { location during passage } \\
\text { of a tornado }\end{array}$} & Right (false) & 1163 (39.7) & $335(34.4)$ & $1498(38.4)$ & \multirow{2}{*}{$\chi^{2}(1)=8.471 ; p<0.01$} \\
\hline & Wrong (true) & $1769(60.3)$ & $638(65.6)$ & 2407 (61.6) & \\
\hline \multirow{2}{*}{$\begin{array}{l}\text { Choose true or false: } \\
\text { tornadoes, like lightning, } \\
\text { never strike the same } \\
\text { place twice }\end{array}$} & Right (false) & $2387(81.4)$ & $858(88.2)$ & $3245(83.1)$ & \multirow[t]{2}{*}{$\chi^{2}(1)=24.007 ; p<0.001$} \\
\hline & Wrong (true) & $546(18.6)$ & 115 (11.8) & $661(16.9)$ & \\
\hline \multirow{2}{*}{$\begin{array}{l}\text { Choose true or false: if you } \\
\text { are driving, you should } \\
\text { take shelter under a } \\
\text { bridge during a tornado }\end{array}$} & Right (false) & $1226(41.9)$ & $435(44.6)$ & $1661(42.6)$ & \multirow{2}{*}{$\chi^{2}(1)=2.229 ; p>0.05$} \\
\hline & Wrong (true) & $1701(58.1)$ & $540(55.4)$ & $2241(57.4)$ & \\
\hline \multirow{2}{*}{$\begin{array}{l}\text { Choose true or false: areas } \\
\text { near mountains are safe } \\
\text { from tornadoes }\end{array}$} & Right (false) & $1934(66.2)$ & $716(73.4)$ & $2650(68.0)$ & \multirow[t]{2}{*}{$\chi^{2}(1)=17.295 ; p<0.001$} \\
\hline & Wrong (true) & $988(33.8)$ & $260(26.6)$ & $1248(32.0)$ & \\
\hline \multirow{2}{*}{$\begin{array}{l}\text { Choose true or false: areas } \\
\text { near populated cities are } \\
\text { safe from tornadoes }\end{array}$} & Right (false) & $2459(84.1)$ & $876(90.4)$ & 3335 (85.6) & \multirow{2}{*}{$\chi^{2}(1)=23.752 ; p<0.001$} \\
\hline & Wrong (true) & $466(15.9)$ & $93(9.6)$ & $559(14.4)$ & \\
\hline \multirow{2}{*}{$\begin{array}{l}\text { Choose true or false: mobile } \\
\text { home parks are more } \\
\text { likely to be hit by a tornado } \\
\text { than other home types }\end{array}$} & Right (false) & $1604(54.8)$ & $509(52.3)$ & $2113(54.2)$ & \multirow[t]{2}{*}{$\chi^{2}(1)=1.929 ; p>0.05$} \\
\hline & Wrong (true) & $1322(45.2)$ & $465(47.7)$ & $1787(45.8)$ & \\
\hline \multirow{4}{*}{$\begin{array}{l}\text { What type of thunderstorm } \\
\text { produces the majority of } \\
\text { significant tornadoes? }\end{array}$} & Right (supercell) & $1339(45.4)$ & $521(52.7)$ & $1860(47.2)$ & \multirow[t]{4}{*}{$\chi^{2}(1)=16.150 ; p<0.001$} \\
\hline & Wrong (squall line) & $416(14.1)$ & $107(10.8)$ & $594(13.3)$ & \\
\hline & Wrong (single cell) & $478(16.2)$ & $116(11.7)$ & $594(15.1)$ & \\
\hline & Wrong (thunderstorm clusters) & $719(24.4)$ & $244(24.7)$ & $963(24.4)$ & \\
\hline \multirow{2}{*}{$\begin{array}{l}\text { Should you open windows } \\
\text { in your home if a tornado } \\
\text { is approaching? }\end{array}$} & Right (do not open) & $2074(70.2)$ & $671(68.1)$ & $2745(69.7)$ & \multirow{2}{*}{$\chi^{2}(1)=1.560 ; p>0.05$} \\
\hline & Wrong (open) & $879(29.8)$ & $314(31.9)$ & $1193(30.3)$ & \\
\hline \multirow{3}{*}{$\begin{array}{l}\text { If you are inside a house and } \\
\text { a tornado is approaching, } \\
\text { where should you go? }\end{array}$} & $\begin{array}{l}\text { Right (to the lowest level: a } \\
\text { basement or storm cellar) }\end{array}$ & $2653(89.9)$ & $929(94.0)$ & $3582(90.9)$ & \multirow[t]{3}{*}{$\chi^{2}(1)=15.486 ; p<0.001$} \\
\hline & $\begin{array}{l}\text { Wrong (to the highest level } \\
\text { in the building) }\end{array}$ & $199(6.7)$ & $41(4.1)$ & $240(6.1)$ & \\
\hline & Wrong (near a window) & $100(3.4)$ & $18(1.8)$ & $118(3.0)$ & \\
\hline \multirow{3}{*}{$\begin{array}{l}\text { If you are outside and there } \\
\text { is no building nearby, } \\
\text { what should you do if a } \\
\text { tornado is coming? }\end{array}$} & $\begin{array}{l}\text { Right (lie flat in a low spot } \\
\text { and use your arms and hands } \\
\text { to protect your head) }\end{array}$ & $2460(83.5)$ & $895(90.6 \%$ & $3355(85.3 \%$ & \multirow[t]{3}{*}{$\chi^{2}(1)=29.784 ; p<0.001$} \\
\hline & $\begin{array}{l}\text { Wrong (move to higher } \\
\text { ground) }\end{array}$ & $149(5.1)$ & $30(3.0 \%$ & $179(4.5 \%$ & \\
\hline & $\begin{array}{l}\text { Wrong (get into a car if } \\
\text { one is nearby) }\end{array}$ & $338(11.5)$ & $63(6.4)$ & $401(10.2)$ & \\
\hline \multirow{3}{*}{$\begin{array}{l}\text { Wherever you are, if you } \\
\text { hear or see a tornado } \\
\text { coming, what should } \\
\text { you do? }\end{array}$} & $\begin{array}{l}\text { Right (take cover right } \\
\text { away) }\end{array}$ & $2391(81.1)$ & $878(88.9)$ & $3269(83.1)$ & \multirow[t]{3}{*}{$\chi^{2}(1)=31.470 ; p<0.001$} \\
\hline & $\begin{array}{l}\text { Wrong (run away from } \\
\text { the tornado as fast as } \\
\text { possible) }\end{array}$ & $346(11.7)$ & $62(6.3)$ & $408(10.4)$ & \\
\hline & $\begin{array}{l}\text { Wrong (stay where you are } \\
\text { and do not move) }\end{array}$ & $210(7.1)$ & $48(4.9)$ & $258(6.6)$ & \\
\hline \multirow{3}{*}{$\begin{array}{l}\text { What is the main cause of } \\
\text { tornadoes? }\end{array}$} & Right (thunderstorms) & $2009(68.0)$ & $761(76.9)$ & $2770(70.3)$ & \multirow[t]{3}{*}{$\chi^{2}(1)=28.316 ; p<0.001$} \\
\hline & Wrong (hurricanes) & $359(12.2)$ & $75(7.6)$ & $434(11.0)$ & \\
\hline & Wrong (tropical storms) & $586(19.8)$ & $153(15.5)$ & $739(18.7)$ & \\
\hline
\end{tabular}


TABLE 9. Tornado knowledge: responses to the question "What should you do if you are in a mobile home and a tornado is occurring?" Given are the count and the percent (in parentheses).

\begin{tabular}{|c|c|c|c|}
\hline Answer & Fixed & Mobile & Total \\
\hline $\begin{array}{l}\text { Right (abandon the mobile } \\
\text { home and seek shelter } \\
\text { in a sturdy, nearby } \\
\text { structure) }\end{array}$ & 1881 (63.6) & $543(54.9)$ & $2424(61.4)$ \\
\hline $\begin{array}{l}\text { Wrong (seek shelter in } \\
\text { the hallway, bathroom, } \\
\text { or closet) }\end{array}$ & $888(30.0)$ & 414 (41.9) & $1302(33.0)$ \\
\hline $\begin{array}{l}\text { Wrong (retreat to a nearby } \\
\text { vehicle) }\end{array}$ & $189(6.4)$ & $32(3.2)$ & $221(5.6)$ \\
\hline
\end{tabular}

findings are similar to prior research (Chaney and Weaver 2010; Chaney et al. 2013).

Prior research also found that people who experience relatively frequent tornado false alarms and missed events have heightened perceptions of inaccuracy, which corresponded with diminished trust in the NWS and lower intentions to act in response to a hypothetical tornado warning (Ripberger et al. 2015). Furthermore, researchers hypothesized that experience with prior false alarms explains why most mobile home residents inadequately prepare for and respond to tornado warnings (Schmidlin et al. 2009). However, mobile home residents in our study report lower perceived false alarm rates compared to fixed home residents. One explanation for these findings is that there is a gap between actual tornado false alarm rates and perceived tornado false alarm rates. Moreover, another possibility is that actual and perceived tornado false alarms may significantly influence mobile home residents' preparedness behaviors. Future research could examine whether tornado false alarm experience and the perception of high tornado false alarm rates in an area influence mobile home residents' preparedness, efficacy to take shelter, and the trust that the government will provide warnings for impending tornadoes.

Additionally, we found that mobile home residents are statistically significantly more likely to engage in prayer, report feeling divine intervention, and believe in God, compared to fixed home residents. Yet, the difference was very small. Future research could test whether there may be possible causal relationship between mobile and fixed home residents' religiosity and their likelihood to prepare for future tornadoes as well as seek safe shelter during tornadoes.

Our findings lead to the following risk communication recommendations. In their tornado risk messages, NWS Weather Forecast Offices (WFOs) should prioritize actions that mobile home residents can take to deal with limited physical supplies and inadequate shelter. For example, WFOs can educate mobile home residents about safe shelter options in their areas. WFOs also can motivate residents to create shelter plans well before they issue tornado watches and warnings. Furthermore, WFOs and their partners can recommend that permanent home residents reach out to neighbors in mobile homes and offer them shelter. Communities also need more local shelters and messages about where these shelters are located, as others have recommended (Chiu et al. 2013). Our findings further suggest that local TV meteorologists may be more effective at reaching mobile and fixed home residents with tornado threat information than government sources. Prior research identified broadcast meteorologists as a primary source for severe weather information (Demuth et al. 2012), especially during the daytime (Mason et al. 2018). Our study adds that mobile home residents are especially dependent on broadcast meteorologists for tornado information.

Given our findings, we suggest that WFOs should continue to develop strong relationships with their local broadcast meteorologists, such as through hosting annual meet-and-greet opportunities. WFOs also should consider working with local broadcast meteorologists at community events, such as sharing a booth at county fairs or severe weather preparedness events. Faith-based institutions also can assist in reaching mobile home communities with preparedness messaging. WFOs should ensure that their weather briefings and forecasts are reaching area faith-based media and organizations. Emergency managers can help identify religious leaders within their communities and disseminate relevant information from WFOs. Additionally, WFOs should consider partnering with broadcast meteorologists to encourage residents to sign up for county text message warning systems, and to keep their cell phones by their beds at night so that they receive these local warnings in addition to warnings from the national government via the Wireless Emergency Alert (WEA) system. As Mason et al. (2018) noted, warning sources such as TV meteorologists are not designed to wake people up at night, when tornadoes often occur in the southeastern United States. Another valuable opportunity for improved risk communication is addressing how to communicate tornado risks to mobile home residents in integrated warning teams. In these teams, NWS forecasters, emergency managers, and broadcast meteorologists collaborate to identify and communicate hazards as a core function of warning systems (e.g., Cavanaugh et al. 2016; Laflin et al. 2017). 
Future research needs to test what types of tornado preparedness messages are most persuasive for mobile home residents. Prior research found that tornado preparedness messages are most persuasive for the general public when they (a) emphasize personal responsibility for planning activities and (b) convince recipients that they possess sufficient resources to manage harmful consequences (Mulilis and Duval 1997). Additionally, prior research argued for understanding "place-based and culturally situated environmental knowledge" to unpack how tornado folk science influences public responses to tornadoes (Klockow et al. 2014, p. 803). Understanding this knowledge may help risk communicators develop persuasive messages. Future research also could test whether emphasizing potential property loss is an effective tornado risk communication strategy. Prior research found that potential property loss is positively associated with personal information seeking (Schumann et al. 2018).

\section{b. Primary channels and sources (RQ2)}

Before taking action in response to warnings, people seek information to confirm and understand warnings (Liu et al. 2016; Mileti and Sorensen 1990). In our study, mobile home residents are less accessible on social media than fixed home residents. For all residents, TV, face-to-face interactions, and phone calls/texts are the primary channels for information exchange during tornadoes. For all residents, meteorologists affiliated with local broadcast stations are the primary source of tornado information, followed by meteorologists affiliated with national TV stations, other media (not meteorologists), and friends.

WFOs and their partners need to be cautious about jumping on a social media bandwagon. Forecasts and warnings still need to be widely distributed through a variety of channels. In the Southeast, many tornadoes occur at night while residents are sleeping (DHS 2017). This means that the first communication mobile home residents receive about a tornado could be a warning. At that point, it may be too late to seek safe shelter. Therefore, messages can encourage mobile home residents to stay tuned to media coverage. Messages also can encourage mobile home residents to obtain NOAA weather radios, if they receive signals in their homes. Broadcast meteorologists can offer regular tornado response tips such as know where your safe shelter is.

\section{c. Tornado risk (RQ3)}

In terms of risk perception, we found that there is not a significant difference in how mobile and fixed home residents evaluate their tornado risk, although mobile home residents have a higher risk of tornado fatalities and property damage. We also found that mobile home residents have lower risk propensity and are less likely to take risks on a daily basis (except personal health risks, such as smoking and drinking) compared to fixed home residents. WFOs and their partners need to elevate mobile home residents' tornado risk perception, perhaps through increasing residents' tornado knowledge (see more below).

\section{d. Tornado knowledge (RQ4)}

Findings indicate that there is room for improving tornado knowledge among all residents, although mobile home residents overall have slightly higher tornado knowledge rates than fixed home residents. Residents may miss critical information about the proper protective actions to take, especially when in mobile homes. Alarmingly, about one-half of the mobile home residents in our study responded that they should seek shelter inside or retreat to a nearby vehicle, rather than seek shelter in a stable structure outside the home when a tornado is "occurring." We offer one important caveat to this finding. It is possible that participants interpreted the question about what actions they would take when "a tornado is occurring" to mean that a tornado is almost near their homes, which could influence respondents to report seeking shelter in a hallway, bathroom, or closet. Additionally, mobile home residents in our study reported statistically significantly lower perceived access to shelter and self-efficacy to take shelter compared to fixed home residents. As prior interview research found, mobile home residents need additional information on when to leave their homes, where to evacuate to, and which route to take (Ash 2017).

Prior research also found that knowledge of tornado shelter locations is a positive indicator of shelter-seeking behavior (Schmidlin et al. 2009). Therefore, the NWS could include tornado shelter locations in their messages via social media. To improve tornado knowledge among mobile home residents and encourage safe protective action, the NWS can include more instructions for mobile home residents to take shelter in nearby sturdy structures. WFOs and their partners also need to continue communicating that mobile home residents should follow the NWS recommendation to not shelter in their homes (NWS 2018a). Another avenue for increasing tornado knowledge is offering online and in-person spotter trainings, especially in communities with high mobile home density. Spotter trainings can help increase mobile home residents' tornado knowledge and build relationships between the Weather Service and mobile home residents. Future research could refine and extend the tornado knowledge questions employed 
in this study, which came from NOAA educational materials (Edwards 2017; NOAA 2010, 2011).

\section{Limitations}

This study has several important limitations. First, the findings about effective tornado communication cannot be generalized to other regions in the United States or other countries. Second, this study employed selfreported measures, which can be affected by retrospective bias (Fischhoff et al. 2005). Third, the data were collected once and longitudinal research could better determine how people respond throughout a tornado season.

\section{Conclusions}

As Brotzge and Donner (2013) noted, "One of the scientific community's greatest achievements in meteorology during the twentieth century has been the development of a largely effective public tornado warning system" (p. 1715). Yet, we know that tornadoes still cause deaths and severe injuries, especially among mobile home residents (Niederkrotenthaler et al. 2013; Schmidlin and King 1995). To help to overcome this obstacle, this study points to avenues for improving tornado communication. There is no magic bullet for effective risk communication, but this study identifies improvements that can save lives.

Acknowledgments. The material presented in the paper is based upon work supported by the National Oceanic and Atmospheric Administration (NOAA) VORTEX-SE Award NA15OAR4590237. The research findings contained in the paper are those of the authors and should not be interpreted as necessarily representing the official policies, either expressed or implied, of NOAA.

\section{REFERENCES}

American Meteorological Society Council, 2000: Policy statement: Tornado preparedness and safety. Amer. Meteor. Soc., accessed 23 July 2017, http://journals.ametsoc.org/doi/pdf/10.1175/ 1520-0477(2000)081\%3C1061\%3APSTPAS\%3E2.3.CO\%3B2.

Anthony, K. E., T. L. Sellnow, and A. G. Millner, 2013: Message convergence as a message-centered approach to analyzing and improving risk communication. J. Appl. Commun. Res., 41, 346-364, https://doi.org/10.1080/00909882.2013.844346.

Ash, K. D., 2017: A qualitative study of mobile home resident perspectives on tornadoes and tornado protective actions in South Carolina, USA. GeoJournal, 82, 533-552, https:// doi.org/10.1007/s10708-016-9700-8.

Ashley, W. S., 2007: Spatial and temporal analysis of tornado fatalities in the United States: 1880-2005. Wea. Forecasting, 22, 1214-1228, https://doi.org/10.1175/2007WAF2007004.1.
Bean, H., B. F. Liu, S. Madden, J. Sutton, M. Wood, and D. Mileti, 2016: Disaster warnings in your pocket: How audiences interpret mobile alerts for an unfamiliar hazard. J. Contingencies Crisis Manage., 24, 136-147, https:// doi.org/10.1111/1468-5973.12108.

Brooks, H. E., and C. A. Doswell III, 2002: Deaths in the 3 May 1999 Oklahoma City tornado from a historical perspective. Wea. Forecasting, 17, 354-361, https://doi.org/10.1175/ 1520-0434(2002)017<0354:DITMOC > 2.0.CO;2.

Brotzge, J., and W. Donner, 2013: The tornado warning process: A review of current research, challenges, and opportunities. Bull. Amer. Meteor. Soc., 94, 1715-1733, https://doi.org/ 10.1175/BAMS-D-12-00147.1.

Brown, S., P. Archer, E. Kruger, and S. Mallonee, 2002: Tornadorelated deaths and injuries in Oklahoma due to the 3 May 1999 tornado. Wea. Forecasting, 17, 343-353, https://doi.org/ 10.1175/1520-0434(2002)017<0343:TRDAII >2.0.CO;2.

Cavanaugh, D., M. Huffman, J. Dunn, and M. Fox, 2016: Connecting the dots: A communication model of the North Texas Integrated Warning Team during the 15 May 2013 tornado outbreak. Wea. Climate Soc., 8, 233-245, https://doi.org/ 10.1175/WCAS-D-15-0047.1.

Chaney, P. L., and G. S. Weaver, 2010: The vulnerability of mobile home residents in tornado disasters: The 2008 Super Tuesday Tornado in Macon County, Tennessee. Wea. Climate Soc., 2 , 190-199, https://doi.org/10.1175/2010WCAS1042.1.

,,-- S. A. Youngblood, and K. Pitts, 2013: Household preparedness for tornado hazards: The 2011 disaster in DeKalb County, Alabama. Wea. Climate Soc., 5, 345-358, https:// doi.org/10.1175/WCAS-D-12-00046.1.

Chiu, C. H., A. H. Schnall, C. E. Mertzlufft, R. S. Noe, A. F. Wolkin, J. Spears, M. Casey-Lockyer, and S. J. Vagi, 2013: Mortality from a tornado outbreak, Alabama, April 27, 2011. Amer. J. Public Health, 103, e52-e58, https://doi.org/10.2105/ AJPH.2013.301291.

Comstock, R. D., and S. Mallonee, 2005: Comparing reactions to two severe tornadoes in one Oklahoma community. Disasters, 29, 277-287, https://doi.org/10.1111/j.0361-3666.2005.00291.x.

Demuth, J. L., R. E. Morss, B. H. Morrow, and J. K. Lazo, 2012 Creation and communication of hurricane risk information. Bull. Amer. Meteor. Soc., 93, 1133-1145, https:// doi.org/10.1175/BAMS-D-11-00150.1.

DHS, 2017: Tornadoes. Department of Homeland Security Ready site, accessed 23 July 2017, http://www.ready.gov/tornadoes.

Dillon, R. L., C. H. Tinsley, and W. J. Burns, 2014: Near-misses and future disaster preparedness. Risk Anal., 34, 1907-1922, https://doi.org/10.1111/risa.12209.

Donner, W. R., 2007: The political ecology of disaster: An analysis of factors influencing U.S. tornado fatalities and injuries, 1998-2000. Demography, 44, 669-685, https://doi.org/10.1353/ dem.2007.0024.

Duck, J. M., and B. A. Mullin, 1995: The perceived impact of the mass media: Reconsidering the third person effect. Eur. J. Soc Psychol., 25, 77-93, https://doi.org/10.1002/ejsp.2420250107.

Edwards, R., 2017: The NOAA online tornado FAQ: Frequently asked questions about tornadoes. Storm Prediction Center, accessed 23 July 2017, http://www.spc.noaa.gov/faq/tornado/.

Fischhoff, B., R. M. Gonzalez, J. S. Lerner, and D. A. Small, 2005: Evolving judgments of terror risks: Foresight, hindsight, and emotion. J. Exp. Psychol. Appl., 11, 124-139, https://doi.org/ 10.1037/1076-898X.11.2.124.

Glass, R. I., R. B. Craven, D. J. Bregman, B. J. Stoll, N. Horowitz, P. Kerndt, and J. Winkle, 1980: Injuries from the Wichita Falls 
tornado: Implications for prevention. Science, 207, 734-738, https://doi.org/10.1126/science.207.4432.734.

Gunther, A. C., and P. Mundy, 1993: Biased optimism and the third-person effect. J. Mass Commun. Quart., 70, 58-67.

Hammer, B., and T. W. Schmidlin, 2002: Response to warnings during the 3 May 1999 Oklahoma City Tornado: Reasons and relative injury rates. Wea. Forecasting, 17, 577-581, https:// doi.org/10.1175/1520-0434(2002)017<0577:

RTWDTM $>2.0 . \mathrm{CO} ; 2$.

Hoekstra, S., K. Klockow, R. Riley, J. Brotzge, H. Brooks, and S. Erickson, 2011: A preliminary look at the social perspective of warn-on-forecast: Preferred tornado warning lead time and the general public's perceptions of weather risks. Wea. Climate Soc., 3, 128-140, https://doi.org/10.1175/2011WCAS1076.1.

Huber, S., and O. W. Huber, 2012: The centrality of religiosity scale (CRS). Religions, 3, 710-724, https://doi.org/10.3390/ rel3030710.

Kim, J.-N., and A. Krishna, 2014: Publics and lay informatics: A review of the situational theory of problem solving. Ann. Int. Commun. Assoc., 38, 71-105, https://doi.org/10.1080/ 23808985.2014.11679159.

Kim, Y., 2016: Understanding publics' perception and behaviors in crisis communication: Effects of crisis news framing and publics' acquisition, selection, and transmission of information in crisis situations. J. Public Relat. Res., 28, 35-50, https:// doi.org/10.1080/1062726X.2015.1131697.

Klockow, K. E., R. A. Peppler, and R. A. McPherson, 2014: Tornado folk science in Alabama and Mississippi in the 27 April 2011 tornado outbreak. GeoJournal, 79, 791-804, https:// doi.org/10.1007/s10708-013-9518-6.

Laflin, J. M., T. B. Pittman, and A. E. Pietrycha, 2017: Core partner collaboration through a joint severe weather functional exercise. 45th Conf. on Broadcast Meteorology/Fourth Conf. on Weather Warnings and Communication, Kansas City, MO, Amer. Meteor. Soc., 4.1, https://ams.confex.com/ams/ 45BC4WXCOMM/webprogram/Paper318435.html.

LaNore, S., 2014: Twister Tales: Unraveling Tornado Myths. Steve LaNore, $134 \mathrm{pp}$.

Liu, B. F., J. D. Fraustino, and Y. Jin, 2015: How disaster information form, source, type, and prior disaster exposure affect public outcomes: Jumping on the social media bandwagon? J. Appl. Commun. Res., 43, 44-65, https://doi.org/ 10.1080/00909882.2014.982685.

,$- \ldots$, and -2016 : Social media use during disasters: How information form and source influence intended behavioral responses. Commun. Res., 43, 626-646, https://doi.org/10.1177/ 0093650214565917.

Liu, S., L. E. Quenemoen, J. Malilay, E. Noji, T. Sinks, and J. Mendlein, 1996: Assessment of severe-weather warning system and disaster preparedness, Calhoun County, Alabama, 1994. Amer. J. Public Health, 86, 87-89, https:// doi.org/10.2105/AJPH.86.1.87.

Mason, L. R., K. N. Ellis, B. Winchester, and S. Schexnayder, 2018: Tornado warnings at night: Who gets the message? Wea. Climate Soc., 10, 561-568, https://doi.org/10.1175/WCAS-D-17-0114.1.

Mileti, D. S., and J. H. Sorensen, 1990: Communication of emergency public warnings: A social science perspective and stateof-the-art assessment. Oak Ridge National Laboratory Rep. ORNL-6609, 160 pp., https://doi.org/10.2172/6137387.

Mulilis, J. P., and T. S. Duval, 1997: The PrE model of coping and tornado preparedness: Moderating effects of responsibility. J. Appl. Soc. Psychol., 27, 1750-1766, https://doi.org/10.1111/ j.1559-1816.1997.tb01623.x.
Nicholson, N., E. Soane, M. Fenton-O'Creevy, and P. Willman, 2005: Personality and domain-specific risk taking. J. Risk Res., 8, 157-176, https://doi.org/10.1080/1366987032000123856.

Niederkrotenthaler, T., and Coauthors, 2013: Injuries and posttraumatic stress following historic tornados: Alabama, April 2011. PLOS ONE, 8, e83038, https://doi.org/10.1371/ journal.pone.0083038.

NOAA, 2010: Thunderstorms, tornadoes, lightning. ...Nature's most violent storms: A preparedness guide, including tornado safety information for schools. National Weather Service Doc. NOAA/PA 201051, 18 pp., accessed 23 July 2017, https:// www.weather.gov/media/owlie/ttl6-10.pdf.

_, 2011: Tornadoes 101-An essential guide to tornadoes: Stay alert to stay alive. National Oceanic and Atmospheric Administration, accessed 23 July 2017, http://www.noaa.gov/ stories/tornadoes-101.

__ 2015: Tornado Outbreak Interface. National Oceanic and Atmospheric Administration Storm Prediction Center, accessed 23 July 2017, https://www.spc.noaa.gov/exper/ outbreaks/.

NWS, 2018a: Severe weather awareness-Tornado classification and safety. National Weather Service Milwaukee/Sullivan Weather Forecast Office, accessed 22 March 2018, https:// www.weather.gov/mkx/taw-tornado_classification_safety. , 2018b: What to do during a tornado. Accessed 22 March 2018, https://www.weather.gov/safety/tornado-during.

Ripberger, J. T., C. L. Silva, H. C. Jenkins-Smith, D. E. Carlson, M. James, and K. G. Herron, 2015: False alarms and missed events: The impact and origins of perceived inaccuracy in tornado warning systems. Risk Anal., 35, 44-56, https:// doi.org/10.1111/risa.12262.

Schmidlin, T. W., and P. King, 1995: Risk factors for death in the 27 March 1994 Georgia and Alabama tornadoes. Disasters, 19, 170-177, https://doi.org/10.1111/j.1467-7717.1995.tb00367.x.

, B. O. Hammer, Y. Ono, and P. S. King, 2009: Tornado shelter-seeking behavior and tornado shelter options among mobile home residents in the United States. Nat. Hazards, $\mathbf{4 8}$, 191-201, https://doi.org/10.1007/s11069-008-9257-z.

Schumann, R. L., K. D. Ash, and G. C. Bowser, 2018: Tornado warning perception and response: Integrating the roles of visual design, demographics, and hazard experience. Risk Anal., 38, 311-332, https://doi.org/10.1111/risa.12837.

Senkbeil, J. C., D. A. Scott, P. Guinazu-Walker, and M. S. Rockman, 2014: Ethnic and racial differences in tornado hazard perception, preparedness, and shelter time in Tuscaloosa. Prof. Geogr., 66, 610-620, https://doi.org/10.1080/ 00330124.2013 .826562$.

Simmons, K. M., and D. Sutter, 2009: False alarms, tornado warnings, and tornado casualties. Wea. Climate Soc., 1, 3853, https://doi.org/10.1175/2009WCAS1005.1.

Sitkin, S. B., and A. L. Pablo, 1992: Reconceptualizing the determinants of risk behavior. Acad. Manage. Rev., 17, 9-38, https://doi.org/10.5465/amr.1992.4279564.

So, J., K. Kuang, and H. Cho, 2015: Reexamining fear appeal models from cognitive appraisal theory and functional emotion theory perspectives. Commun. Monogr., 83, 120-144, https://doi.org/10.1080/03637751.2015.1044257.

Trainor, J. E., D. Nagele, B. Philips, and B. Scott, 2015: Tornadoes, social science, and the false alarm effect. Wea. Climate Soc., 7, 333-352, https://doi.org/10.1175/WCAS-D-14-00052.1.

Troutman, T. W., L. J. Vannozzi, and J. T. Fleming, 2001: The implications of educating the public regarding NOAA weather radio reception and placement within a structure. 
Bull. Amer. Meteor. Soc., 82, 2769-2772, https://doi.org/ 10.1175/1520-0477(2001)082<2769:TIOETP>2.3.CO;2.

van der Pligt, J., W. Otten, R. Richard, and F. van der Velde, 1993: Perceived risk of AIDS: Unrealistic optimism and selfprotective action. The Social Psychology of HIV Infection, J. B. Pryor and G. D. Reeder, Lawrence Erlbaum Associates, 39-58.

Weber, E. U., 2006: Experience-based and description-based perceptions of long-term risk: Why global warming does not scare us (yet). Climatic Change, 77, 103-120, https://doi.org/10.1007/ s10584-006-9060-3.
Whitmer, D., V. Simms, and M. E. Torres, 2017: Assessing mental models of emergency through two knowledge elicitation tasks. Hum. Factors, 59, 357-376, https://doi.org/10.1177/0018720816672117.

Witte, K., K. A. Cameron, J. K. McKeon, and J. M. Berkowitz, 1996: Predicting risk behaviors: Development and validation of a diagnostic scale. J. Health Commun., 1, 317-341, https:// doi.org/10.1080/108107396127988.

Zinkhan, G. M., and K. W. Karande, 1991: Cultural and gender differences in risk-taking behavior among American and Spanish decision makers. J. Soc. Psychol., 131, 741-742, https://doi.org/10.1080/00224545.1991.9924657. 